Transcontinentales

continentales

Sociétés, idéologies, système mondial

Afrique plurielle

\title{
Asie méridionale
}

\section{(2) OpenEdition \\ 1 Journals}

Édition électronique

URL : http://journals.openedition.org/transcontinentales/1495

DOI : 10.4000/transcontinentales. 1495

ISBN : 978-2-8218-1408-0

ISSN : 1775-397X

\section{Éditeur}

Editions de la maison des sciences de l'homme

\section{Édition imprimée}

Date de publication : 30 juin 2006

Pagination : 188

ISBN : 2200-92169-1

ISSN : $1950-1684$

\section{Référence électronique}

«Asie méridionale», Transcontinentales [En ligne], 2 | 2006, document 30, mis en ligne le 15 décembre 2012, consulté le 25 septembre 2020. URL : http://journals.openedition.org/transcontinentales/1495 ; DOI : https://doi.org/10.4000/transcontinentales.1495

Ce document a été généré automatiquement le 25 septembre 2020.

Tous droits réservés 


\section{Asie méridionale}

1 GERVAIS-LAmbony Philippe, Frédéric LANDy et Sophie oldField (éds), Reconfiguring Identities and Building Territories in India and South-Africa, New Delhi, Manohar/CSH, 2005, 346 p.

2 GOSH Archana et Stéphanie TAWA LAMA-REWAL, Democratization in Progress. Women and Local Politics in Urban India, New Delhi, Tulika Books, 2005, 158 p.

3 HUST Evelyn et Michael MANN (éds), Urbanization and Governance in India, New Delhi, Manohar, 2005, 345 p.

4 OLIVEAU Sébastien, CSH Occasional Paper. Periurbanisation in Tamil Nadu: A Quantitative Approach, New Delhi, French Research Institutes in India, 2005, 90 p.

5 RUET Joël, Privatising Power Cuts? Ownership and Reform of State Electricy Boards in India, New Delhi, Academic Foundation/ CSH, 2005, 339 p.

6 RUET Joël (éd.), Against the Current (volume II). Fixing Tariffs, Finance and Competition for the Power Sector in India, New Delhi, Manohar/CSH, 2005, 193 p. 